\title{
Public space or safe space - remarks during the COVID-19 pandemic
}

\author{
Artur Jasiński \\ a.jasinski@ajbiuro.pl | (1) http://orcid.org/0000-0002-5285-8143 \\ Department of Architecture and Fine Arts, Andrzej Frycz Modrzewski Kraków \\ University
}

\author{
Scientific Editor: Mateusz Gyurkovich, \\ Cracow University of Technology \\ Technical Editor: Aleksandra Urzędowska, \\ Cracow University of Technology Press \\ Language Editor: Tim Churcher, Big Picture \\ Typesetting: Anna Basista, Cracow \\ University of Technology Press
}

Received: May 21, 2020

Accepted: June 25, 2020

Copyright: @ 2020 Jasiński. This is an open access article distributed under the terms of the Creative Commons Attribution License, which permits unrestricted use, distribution, and reproduction in any medium, provided the original author and source are credited.

Data Availability Statement: All relevant data are within the paper and its Supporting Information files.

Competing interests: The authors have declared that no competing interests exist.

Citation: Jasiński, A. (2020). Public space or safe space - remarks during the COVID-19 pandemic. Technical Transactions. e2020020. https://doi.org/10.37705/ TechTrans/e2020020

\begin{abstract}
The coronavirus COVID-19 outbreak and its immediate impact on all aspects of human life have changed the way we use public space in our cities. People have been forced to adopt social isolation measures and wear masks. Street life has ground to a halt and public transport use has plummeted, while social facilities such as restaurants, clubs and cinemas have been closed. The relationship between private and public space has been reversed: public space has become deserted while private space, one of luxury, has been available only to the richest. The behaviour and interactions between people in public space have also changed. The paper analyses the above phenomena and raises questions about the future of metropolitan public spaces after the COVID-19 pandemic.
\end{abstract}

Keywords: public space, private space, physical distancing, social segregation, mediatisation of life 


\section{Introduction}

The article Metropolitan Dilemma - Public Space or Safe Space published in 2009 analysed how terrorism and counter-terrorism measures contributed to the transformations and changes in the functioning of public urban space. It also mentioned derivative phenomena, such as limited access to public space, and addressed the impact of IT technologies, including ubiquitous electronic surveillance, on the limitation of the personal freedom of citizens. The conclusion was that excessive or inappropriate counter-terrorism measures that fail to match the scale of the threat and defy the essence of the city as free public space may lead to greater social, psychological and spatial damage than terrorism itself (Jasiński, 2009). In short - the cure may sometimes be worse than the disease.

The outbreak of the COVID-19 pandemic and the related changes it has brought to community life and the functioning of our cities require a process of re-addressing the new phenomena and verifying the transformations that the public space around us is currently undergoing from the perspective of security and with regard to the numerous costs generated by the anti-virus restrictions and limitations imposed in the name of public security. The discussion below focuses on the most important impacts of the pandemic concerning the shape and functioning of public space.

\section{Space is luxury}

Stawomir Gzell claims that the space that we have at our disposal is the most highly valued commodity nowadays. Space is luxury, he states. He adds:

I mean physically mappable space, the distance between people in an apartment, at work, in the street, in a city square, in public transport. It is a luxury to be able to calibrate these distances independently, as you wish, in consultation with your partners and fellow citizens, without the conditions imposed by the crowd on the tram, by the traffic jams in the streets, by square metre savings in offices or universities (Gzell, 2015: 97).

Gzell addresses both public space and private space. At this point, it must be noted that the pandemic has visibly increased the value of private space, which provides both invaluable safety from the epidemic and the mental comfort which is indispensable during isolation. When city squares and streets become empty and people crowd in their homes, they find shelter in their own, private gardens, vast roof terraces or vacation cabins (not to mention private islands), which shield them from others, who constitute potential sources of infection.

Social behaviour always radically changes during a pandemic. It is a time when the best protective measure is to increase physical distance and, preferably, to isolate oneself completely. This is how 18th century London was described:

There were also too many people forced into too small a space, and this massive overcrowding in narrow streets engendered strange fevers and excitements. That is why the instinctive fear of the mob, or crowd, had as much to do with its propensity for disease as its prevalence towards violence. London as transmitted by its citizens, which went back to the times of fever and of epidemic plague when [...] their hands would infect the things they touched [...]. People were afraid of touch, of the unhealthy warmth of London passing from inhabitant to inhabitant (Ackroyd, 2011: 413-414).

The fear of becoming infected not only invokes anxiety over contact with strangers and the desire to flee the city but it also changes the way people travel: they walk rather than take a tram, ride a bike instead of going by bus, choose a private car over a train. Planes are grounded anyway. 
Fig. 1. Socially distanced street protest in Tel Aviv, photo: Oded Balility (source: https://www.charlotteobserver.com/news/ article242394556.html)
During a pandemic, the erosion of public space is accompanied by the privatisation of travel, where the car is no longer just a vehicle but also a fairly safe shelter. Some dogmas of modern urban planning, such as the desire to increase building and population density, are also challenged. Vishaan Chakrabarti, the Director of Urban Planning in the administration of New York Mayor Michael Bloomberg, writes the following in his manifesto: "If you love nature, do not live in it". He also adds that you should give up the car, use the underground and live in a tall and hyperintense city, as "adopting a truly urban lifestyle is clearly the "greenest" and most sustainable choice one can make" (Chakrabarti, 2013: 78-81). This eco-friendly commitment to limit the space occupied by buildings and reduce our ecological footprint and inhibit the urban sprawl is challenged during the pandemic by the view of children playing on swings set up in suburban gardens, while all the children crowded in blocks of flats can do is sing on the balconies, accompanied by their parents of course, to lift the spirits of and pay tribute to the hard-working physicians.

Jane Jacobs, an icon of contemporary urban movements, advocated increasing building density and bringing people back to downtown streets. She also sneered at empty city parks: "More Open Space for what? For muggings? For bleak vacuum between buildings?” (Jacobs, 1993: 117). In the meantime, during a pandemic, green city areas, such as parks, waterfronts, boulevards, and common meadows are invaluable open-air resources where people can take advantage of the lowdensity space to find relatively safe refuge outdoors from the harshness of being locked inside their homes and living in social isolation. In this context, the decision of the Polish government to shut down parks, forests and river waterfronts for the public and severely fine those breaking the restriction was incomprehensible.

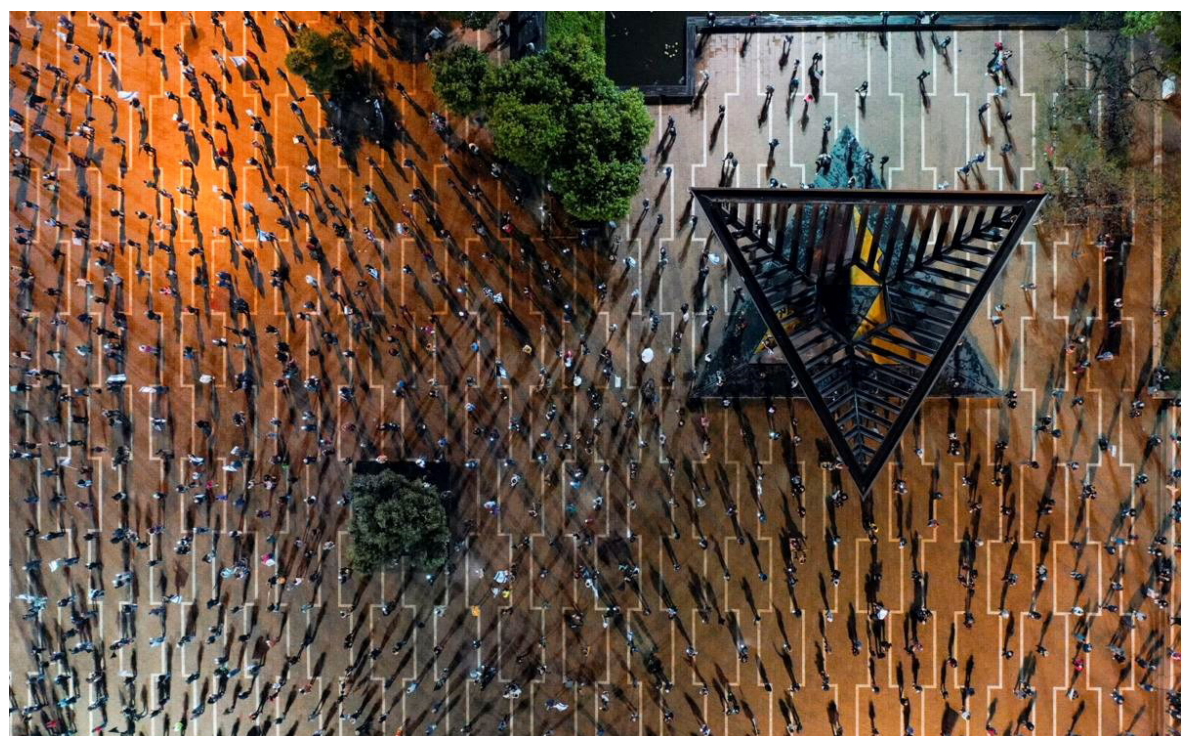

Jacobs praised the benefits of intense street life, population diversity and the dense concentration of buildings:

However, it still remains that dense concentrations of people are one of the necessary conditions for flourishing city diversity. And it still follows that in districts where people live, this means there must be a dense concentration of their dwellings on the land pre-empted for dwelling. The other factors that influence how much diversity is generated, and where, will have nothing much to influence if enough people are not there (Jacobs, 1993: 267).

She also claimed: "This is something that everybody knows: A well-used city street is apt to be a safe street. A deserted city street is apt to be unsafe" (Jacobs, 1993: 44). It seems to be the other way round during a pandemic - a deserted street has become a safe place, at least in terms of coronavirus exposure. 


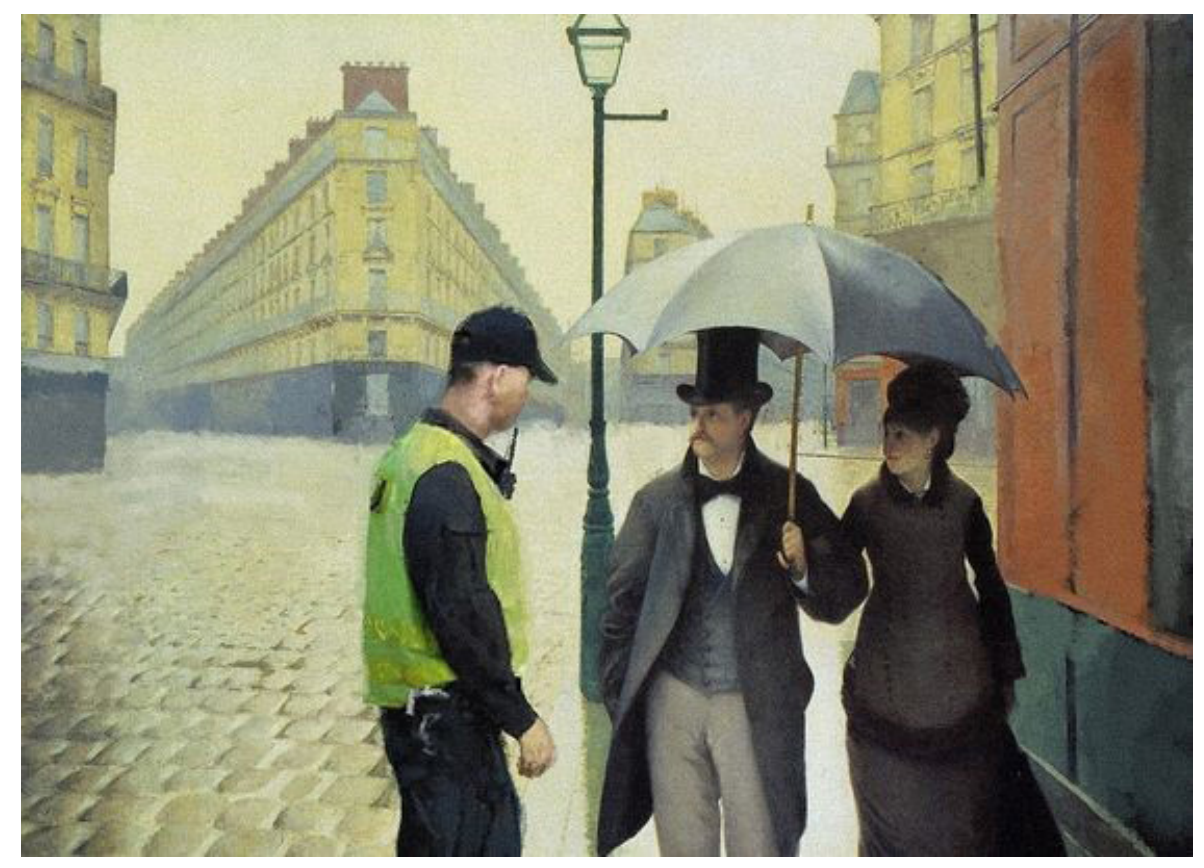

\section{Anonymous, masked citizen}

One of the basic methods of fighting a pandemic is the requirement to wear a mask that covers the nose and mouth when in a public space. It is not only personal protection, it is also a sign of altruism and social solidarity in the global response to pandemic (Cheng et al., 2020). The requirement was introduced in Poland in the middle of April 2020, and it rendered the meetings of people in public space unrecognisable. Until recently, governments of many European countries fought with the custom of women covering their faces in public space for religious reasons. Face coverings such as burkas, veils, hijabs and chadors were banned in a number of countries: in France in 2011, in Germany in 2016, in Austria in 2017. The decisions were usually motivated by public security concerns or by a bill to ban religious symbols in public space. People were also prohibited from covering their faces during public gatherings and demonstrations. The famous Guy Fawkes masks adopted in 2008 by the anarchist movement Anonymous date from that period.

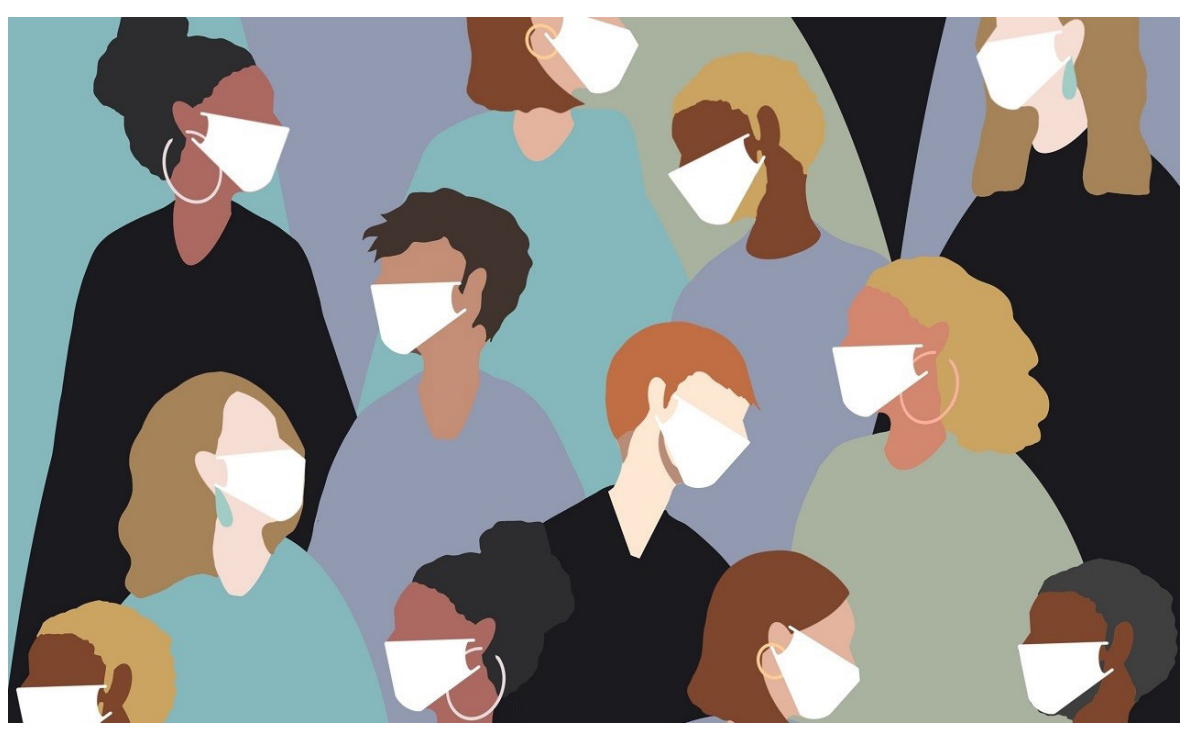

Fig. 2. Jarek Kubocki: Gustave Caillebotte, Paris a Rainy Day, 32nd day of Covid-19 Quarantine (source: https://indepest. com/2020/04/10/32nd-day-of-quarantine)
Fig. 3. Masked citizen: new relations between people in public space (source: https://www. transparency.org/news/feature/corruption_. could_cost_lives_in_latin_americas_response_ to_the_coronavirus) 
The need to maintain full eye contact and read the signals communicated by facial expression is one of the basic principles ensuring the comfort and safety of strangers within a shared space. In his analysis of human behaviour in public space, Erving Goffman mentions a specific set of rules, conventions and norms that he calls 'conventions in conduct in situations.' The first convention he lists, and the most fundamental, is facial engagement - a set of facial movements and looks that strangers use to communicate in shared space. "One of the most evident means by which the individual shows himself to be situationally present is through the disciplined management of personal appearance" (Goffman, 2008: 33). Our looks, body language and tone of voice are codified and they have specific social meanings - they may either help start a conversation and friendly interpersonal interaction or, alternatively, invoke fear or aggression.

By contrast, masked faces not only make it difficult to distinguish between people we know and strangers but also prevent us from properly reading interpersonal signals and can also evoke various responses and emotions. For some people, being masked increases the inclination towards aggressive and abnormal behaviour, towards breaking what belongs to the community (Wysocki, 2020: 18). Others, on the other hand, experience alienation and feel lost while wearing masks. The Polish actress Agata Kulesza says: "Whenever I put on a mask, I look down. I am walking down the street and I bump my head into this guy, huge like a mountain, who I hadn't seen. Why? I have no idea. Perhaps I'm hiding, like a bank robber" (Smoleński, 2020: 26). Other press reports mention cases of antisocial public behaviour, xenophobia and racial stereotyping. Sometimes people with different skin colours or even doctors, accused of spreading the disease, are attacked in public places.

New technologies and the behaviour they induce can be a source of conflict. A well-known example is the use of mobile phones in public space and in the streets: at first it caused annoyance: No, you can't walk and talk at the same time was the title of a New York newspaper article (Belson, 2004). Now this is something common, a norm, even if having a phone conversation, especially a loud one, in a restaurant is still considered bad taste. The observed tendency of individuals to seek isolation in a crowd also leads to certain problems: Mobile phones used by public transport passengers, cyclists and pedestrians allow them to sink into the music and alienate themselves from reality, where they are present only in body. Wearing masks, sunglasses, hats and headphones, they cross over to another dimension of virtual space, one that is cut off from the surrounding world. These phenomena, referred to as the privatisation and appropriation of public space, change customs and etiquette, and destroy the main attraction of city life - the pleasure of safely being around people, walking together and talking.

\section{Physical distancing and social segregation}

In his famous book "The Hidden Dimension," Edward Hall defined four interpersonal distances around the human body, depending on cultural patterns. He identified intimate distance, personal distance, social distance and public distance, and then assigned appropriate spatial measures to each one (Hall, 2001: 145-164). Personal distance, which we can refer to for the purpose of this paper as private distance, was defined by Hall as $45-75 \mathrm{~cm}$ (close phase) and 75-120 cm (far phase) for Western culture. It seems that the COVID-19 pandemic will increase personal distance to a desired value of $180 \mathrm{~cm}$. The expansion of private space will most likely entail far-reaching changes in social behaviour in public space and the way in which this space is used: from restaurant tables being farther apart and distances between people sitting on benches marked with tapes - to aggressive, or perhaps even violent, responses to personal space violations. The results will include an increasingly individualistic approach to public space and its progressing atrophy. 


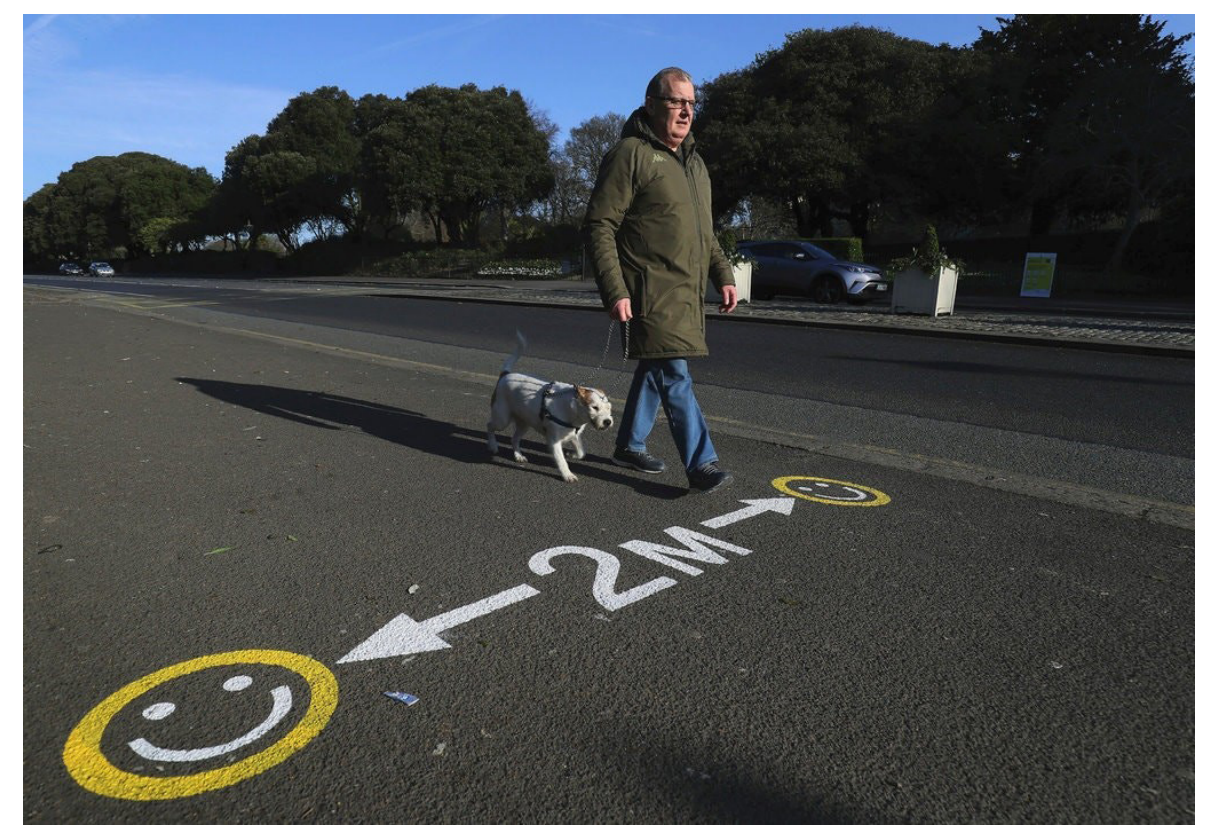

The pandemic will result in further financial and social stratification: some will rapidly grow rich due to the opportunities offered by the pandemic (electronic and social media, e-commerce, medical concerns) while many others (small businesses, production, trade and services), directly affected by the economic consequences of the crisis, will lose their jobs and face poverty. The phenomena will be intensified by the further development of machine learning and artificial intelligence, which will significantly reduce the number of jobs. This will break physical contact between people from various social strata.

The transformation of urban forms caused by economic phenomena and the development of digital technologies was addressed by Manuel Castells (Castells, 2007: 381-428). He claims that the merger of elites and the segmentation and disorganisation of the masses are the twin mechanisms of social dominance developing in our societies. Elites live in a separated space, including worldwide connections and spaces for flows: international hotels, airports and the corporate world of services and comforts, with continuous, personal online access to ICT networks. Members of elites belong to an international culture whose identity is not connected with any specific society. Elites are cosmopolitan while other people are local. People still live in cities but experience related to places becomes abstracted from network-based and ahistorical power, which results in structural schizophrenia between two spatial logics, which threatens to break down communication channels in society, as Castells concludes in his deliberations.

The deliberations by Castells highly resemble the dystopian vision of cities of the future depicted by American geographers from Los Angeles Michael J. Dear and Steven Flusty. They believe that a post-modern society will split into two basic groups: the cybergeoisie, comprising the owners of controlling interests, directors and key employees of reduced corporations, celebrities and a small number of representatives of creative professions, and the protosurps, a growing group of people without regular jobs, the global surplus labour hired on a temporary basis, alienated from the global production process but still participating in the consumption process.

Cybergeoisie live in guarded, eco-friendly areas - cyburbia, located in the hills around cities. The luxurious cyburbia, with sports and leisure facilities, schools and culture venues, will be connected with a teleintegration network, managed and overseen by citidels - corporate towers controlling the global latifundia.

The in-beyond space inhabited by protosurps will provide cheap labour, organised as a patchwork of various social groups where none can dominate over
Fig. 4. Markings on pathways in a Dublin park encourage people to maintain their distance. Credit... Brian Lawless/Press Association, via Associated Press (source: https://www.nytimes. com/2020/04/08/opinion/coronavirus-tipsnew-york-san-francisco.html) 
the others. This will be an urban province in the IT aspect, supported by basic phone and telegraphic systems, supervised and, if needed, modified by a disinformation superhighway which disseminates current ideologies and beliefs, creates needs and dreams and gives symbolic values to household necessities. It is also a sophisticated medium used by the inhabitants of in-beyond to observe and understand the world around them. This socio-spatial system is termed by the authors of Postmodern Urban Condition (Dear, Flusty, 1999: 78).

\section{Digitalisation of social life}

The phenomenon of social activity being transferred from public space to virtual space has been mentioned by numerous researchers for quite some time. Ewa Rewers notes that in the post-industrial city, the agora was moved to the space of electronic media (Rewers, 2005: 5). Her opinion is repeated by Stawomir Gzell:

The street of tomorrow takes the form of an information superhighway, while a teleport is the agora. Cities need these investments and many have already started them. The allocation of the jobs required for the work to be performed may transform the streets of the future city, because we will use them less often. But will a time come when they become completely useless in the form we have been accustomed to for centuries? (Gzell, 2008: 114).

At the same time, with many functions of the city moving to virtual space, its saturation with security and surveillance systems based on digital technology grows. The leading modern technologies used to monitor public spaces are: biometrics, CCTV, smart identification cards and electronic devices monitoring and tracking the communication of information (Lyon, 2006: 297-311). Ever since September 11, these types of sophisticated technology and device, used originally to secure the most closely guarded military facilities, government buildings and banks, see ever more applications in the monitoring of public space. Surveys show that ordinary people facing crime prefer safety over privacy (Van Heek et al., 2015). Digital video cameras ensure the continuous surveillance of city streets and squares; they help identify car registration numbers and, when combined with biometric databases, they make it possible to identify faces in just a few seconds. Mobile phones follow us all the time and permit the tracking of not just where we have been but also our network of contacts

Fig. 5. A London street setting, pre-pandemic (photo by author)

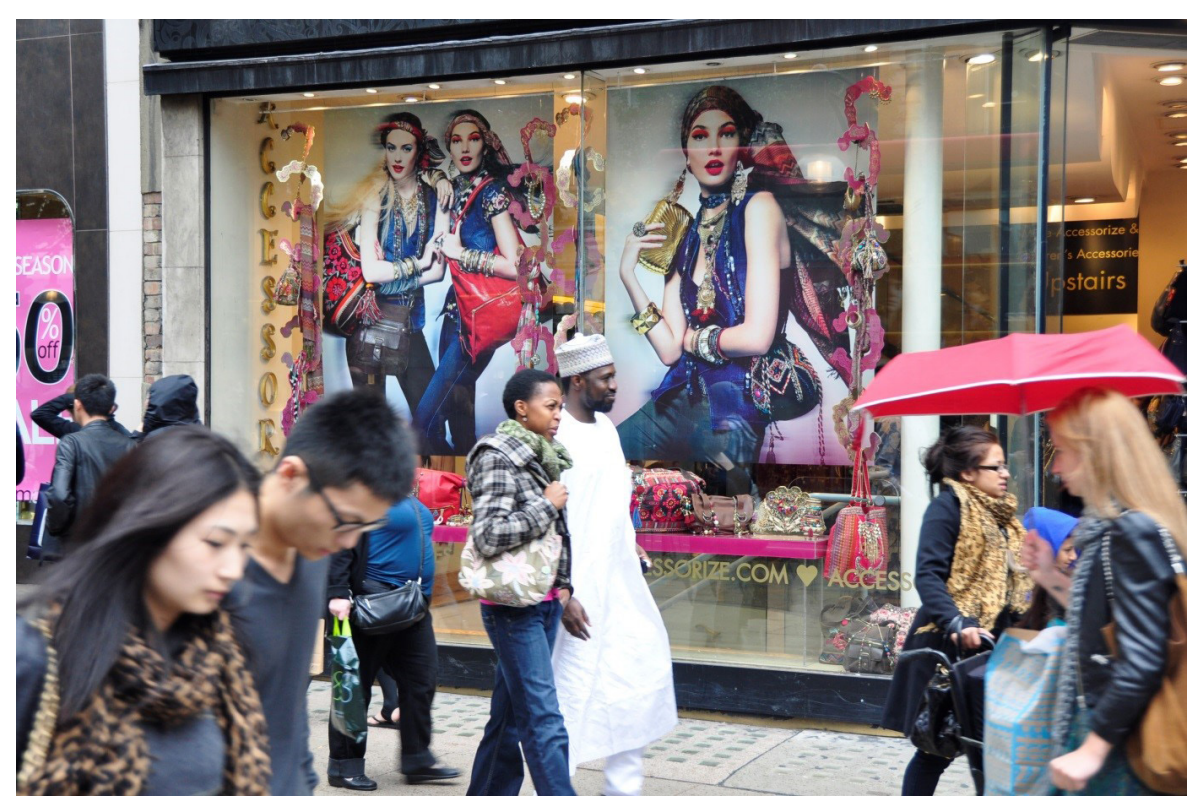


and meetings. The Automated Socio-Technical Environment (AESTE) systems described by Lianos and Douglas where the whole city infrastructure is coupled by a surveillance and monitoring system automatically responding to various threats, including terrorism and pandemic diseases, are increasingly more likely to be created (Coafee, 2006: 294-295).

The coronavirus pandemic has increased the significance of digital technology. The role of IT is heightened as digital space becomes a platform for sharing information and enabling human contact and interaction. We are informed about biometric developments permitting facial recognition under masks, about the combining of biometric readers with sensors measuring body temperature to identify sick people in the crowd or about the use of mobile phones to track the locations of particular people and to recreate the network of their personal and social contacts. News sites, social media and digital technologies for online remote work are gaining in importance. Courier service activity and product delivery based on online shopping is developing rapidly. And, consequently, so is the need to continuously protect oneself - the amount of waste produced in households, mainly plastics and cardboard, is growing rapidly.

\section{The power of the crowd and the vitality of the city}

More or less utopian projects of rebuilding the city and its public space have continued to emerge over the years: the right-wing intellectual Roger Scruton advocates a return to the idea of a nation state, a local social community and citizenship within a territorial jurisdiction, in order to "limit globalization, perceived as a threat that the West brings to the rest" (Scruton, 2003: 145-147); while the left-leaning Zygmunt Bauman advocated rebuilding the local community," hoping for it to give shelter from the waves of global chaos - the waves that come from distant places and cannot be controlled by any single local forces" (Bauman, 2008: 191). Krzysztof Nawratek presented a political project of an active "Plug-in Citizen" as a prerequisite for the reconstruction of the Polis:

After the death of the City, we can expect something new to emerge, something that will allow people who live in highly populated small spaces to reinvent themselves. The death of the City may mean the resurrection of the Polis. The Polis, understood as self-management by a community who live in an 'urban area' that was formerly called a city (Nawratek, 2008: 16).

Other researchers claim that nowadays, public order means a lack of necessity for interhuman contact. Richard Sennett claims:

Once a mass of bodies packed tightly together in the centres of cities, the crowd today has dispersed. It is assembled in malls for consumption rather than for the more complex purposes of community or political power. [...] In the modern crowd the physical presence of other human beings feels threatening (Sennett, 1966: 15).

The question remains: will the sense of threat disappear once a vaccine is invented, will theatres and cinemas be filled again, will tourists return to airports and exotic beaches, will the streets of our cities ever be crowded again?

\section{Conclusion}

The COVID-19 pandemic will change the patterns of behaviour in public space and the rules of spatial planning. Chairs will be further apart in street cafés, park benches will be marked with tapes to ensure the desired personal distance and some streets may be closed and converted to pedestrian zones. More people will probably walk and cycle. Family bonds, and maybe also neighbourly bonds, 
will be strengthened. Differences between the rich and the poor will grow, the value of private space will increase and prices of large, attractive properties will go up. This will be accompanied by the concurrent atrophy of public spaces as their functions are gradually taken over by the Internet and by social media. Digital technologies for online work, entertainment and shopping will develop quickly while electronic surveillance over citizens and public spaces will be reinforced.

But the essence of the city will not change, and urban decorations will remain untouched. A city without people is dead. A city is indispensable for a community to live. There is no city without people, there is no society without cities, and there is no civilisation without society. The observation of cities leads to the conclusion that they resemble living creatures, both in their organic structures and in their spontaneous functioning. A city is a creation that undergoes continuous spatial transformation, adapting to various economic conditions and responding to diverse social needs. And so we can reverse the problem and ask ourselves: how will cities cope with the consequences of the COVID-19 pandemic?

There is no doubt they will cope. Us as planners, architects and regular citizens can help them. The future may be unclear, the duration and the consequences of the pandemic remain unknown, but in this uncertain situation, we can adopt two modes of action: either do nothing, wait to see what the future brings, or do anything to make our lives in cities better and improve the quality of their public space. In this endeavour, the pandemic can assist us.

\section{References}

Ackroyd, P. (2001). Londyn. Biografia. Warszawa: Zysk i Spółka.

Bauman, Z. (2008). Wspólnota. Kraków: Wydawnictwo Literackie.

Belson K. (2004). Sidewalk Smackdown; No, You Cant't Walk And Talk AT the Same Time, The New York Times 29.08.2004. Retrieved from: https://www.nytimes. com/2004/08/29/weekinreview/sidewalk-smackdown-no-you-can-t-walk-and-talkat-the-same-time.html (date of access: 2020/05/15).

Castells, M. (2007). Społeczeństwo sieci. Warszawa: Wydawnictwo Naukowe PWN.

Chakrabarti, V. (2013). A Country of Cities. A Manifesto for Urban America. New York: Metropolis Books.

Cheng, K.K., Lam, T.H., Leung, C.C. (2020). Wearing face masks in the community during COVID-19 pandemic: altruism and solidarity, Lancet. www.lancet.com published online April 16, 2020, https://doi.org/10.1016/S0140-6736(20)30918-1

Coaffee, J. (2004). Terrorism, Risk and the City. The making of a contemporary Urban Landscape. Hants: Ashgate Publishing.

Dear, M., Flusty, S. (1999) The Postmodern Urban Condition. In M. Featherstone, S. Lash (Eds.), (pp. 64-85) Spaces of Culture. City - Nation - World. London: SAGE Publications.

Goffman, E. (2008). Zachowanie w miejscach publicznych: o społecznej organizacji zgromadze. Warszawa: Wydawnictwo Naukowe PWN.

Gzell, S. (2008). Miasto jako przedmiot badań urbanistyki. In: B. Jałowiecki (Ed.), Miasto jako przedmiot badań naukowych w poczq̨tkach XXI wieku (pp. 11-27). Warszawa: Wydawnictwo Naukowe Scholar.

Gzell, S. (2015). W jakim mieście chciałbym mieszkać? In A. Jasiński (Edd), Wolny rynek, lepsze miasto? 25 lat wolnorynkowych doświadczeń polskiej architektury (pp. 95104). Kraków: SARP.

Hall, E.T. (2001). Ukryty wymiar. Warszawa: Muza SA.

Jacobs, J. (1993). The Death and Life of Great American Cities. New York: The Modern Library.

Jasiński, A. (2009). Wielkomiejski dylemat - przestrzeń publiczna czy przestrzeń Bezpieczna /Metropolitan Dilemma - Public Space or Safe Space. Przestrzeń i Forma 12/2009, 319-352. ISSN 1895-3247 
Lyon, D. (2006). Technology vs. „Terrorism”: Circuits of City Surveillance Since September 11, 2001. In S. Graham (Ed.), Cities, War and Terrorism. Malden: Blackwell Publishing. Nawratek, K. (2008). Miasto jako idea polityczna. Kraków: Korporacja Hal'art.

Rewers, E. (2005). Post-Polis. Wstęp do filozofii ponowoczesnego miasta. Kraków: Universitas.

Scruton, R. (2003). Zachód i cała reszta. Globalizacja a zagrożenie terrorystyczne. Poznań: Zysk i S-ka.

Sennett, R. (1966). Ciało i kamień. Człowiek i miasto w cywilizacji zachodu. Gdańsk: Aletheia.

Smoleński, P. (2020). No i co, siedzi Pani teraz na d...? rozmowa z Agatą Kuleszą, Gazeta Wyborcza, 25-26.06.2020, p. 26.

Van Heek, J., Arning, K., Ziefe, M. (2015). Safety and privacy perceptions in public spaces: An empirical study on user requirements for city mobility, RWTH Aachen University. https://doi.org/10.1007/978-3-319-19743-2_15

Wysocki, G. (2020). Koronawirus w głowach, rozmowa z Michatem Bilewiczem i Michatem Łuczewskim, Gazeta Wyborcza, 25-26.06.2020, p. 18. 